DOI https://doi.org/10.36059/978-966-397-116-2/258-277

\title{
FORENSIC EXAMINATION ON INTELLECTUAL PROPERTY AS AN INSTITUTE OF PROTECTION OF CRITICAL INFRASTRUCTURE IN UKRAINE: GENESIS, CONCEPT AND SYSTEM
}

\section{Fedorenko V. L.}

\section{INTRODUCTION}

The development of modern states implies the effective protection of their rights to intellectual property ${ }^{1}$. After all, these objects today are no less important indicator of the country's economic, social, cultural and spiritual potential than its financial resources or minerals. It is not in vain that the key to the development and prosperity of the intellectually inherent economies of most of the member states of the European Union, the USA, Japan, Singapore, South Korea, and others became the most developed systems of administrative and judicial protection of the right to objects of intellectual property rights in the 21 st century.

For Ukraine, the problem of developing and improving an effective system of protection of rights to intellectual property objects is, on the one hand, the issue of preserving and increasing the domestic intellectual capital, a kind of 'intellectual matrix' of Ukraine's critical infrastructure, and on the other hand a narrative for European integration through the implementation of the provisions of the Agreement on the association of Ukraine with the EU and other international obligations of our state in the field of protection of intellectual property. It should be noted that despite the known shortcomings in the field of law-making and enforcement practice in protecting the rights to intellectual property objects in Ukraine, Ukraine's successes in this area are also prominent and promising. In particular, in the years 2002-2019, the forensic examination on intellectual property has been established and developed. It is not analogous in most countries of the world. In 2019, the Supreme Court on Intellectual Property will begin its work; a number of initiatives supported by the public have been introduced to the Parliament, which should improve the

\footnotetext{
${ }^{1}$ Fedorenko W. Udział ekspertów sądowych w ochronie praw własności intelektualnej na Ukrainie i za granicą / W. Fedorenko // Nowe wyzwania i rozwiązania w europejskim systemie ochrony praw człowieka. Red. naukowa J. Jaskiernia, K. Sprzyszak. - Toruń: Wydawnictwo Adam Marszałek, 2018. - S. 510-512.
} 
existing legislation on the protection of copyright and related rights, inventions and industrial designs, etc.

\section{The concept and genesis of forensic examination of objects of intellectual property rights}

The right to intellectual property was first laid down in English by the Statute of Queen Anne (1710). According to it, it was forbidden to print and reprint books without the consent of the authors and set a 14-year term of copyright protection. In 1774, this provision was implemented by the court in the decision on the Donaldson vs. Beckett case, which protected the 14-year copyright term of Donaldson ${ }^{2}$.

Centuries later, the right to intellectual property was secured in the Constitution of the State of Massachusetts in 1789. Its provisions have regulated that 'there is no property that belongs to a person more than that which is the result of its intellectual work'. Similar provisions were also found in the constitutions of the former European countries like Denmark, Norway, Prussia, Saxony, and others ${ }^{3}$.

The very category of 'intellectual property' was first introduced in general use in 1850 by Libertarian L. Spooner (1808-1887) only ${ }^{4}$. And the consolidation of the legal regime for the protection of intellectual property at the international level took place several decades later. Thus, in 1883, intellectual property was enshrined in one of the first international treaties in this area in the Paris Convention for the Protection of Industrial Property $^{5}$, and in 1886, in the Berne Convention on the Protection of Literary and Artistic Works, which operates today, with the latest changes in $1979^{6}$.

Over time, the provisions of international treaties on the protection of the right to intellectual property, first of all a copyright, were embodied in the end of 19th - at the beginning of the 20th century in the legislation of many European countries. In particular, the Austrian Copyright Act for literary and artistic works and photographs of December 26, 1895 and the

\footnotetext{
2 Бетелл Т. Собственность и процветание : уроки истории / Томм Бетелл ; пер. с англ. Б. Пинскера. - М. ; Челябинск : Социум, 2018. - С. 353.

${ }^{3}$ Охорона інтелектуальної власності в Україні / С.О. Довгий, В.О. Жаров, В.О. Зайчук та ін. - К. : Форум, 2002. - С. 5.

4 Бетелл Т. Собственность и процветание : уроки истории / Томм Бетелл ; пер. с англ. Б. Пинскера. - М. ; Челябинск : Социум, 2018. - С. 351-353.

5 Паризька конвенція про охорону промислової власності від 20 березня 1883 року (укр/рос) // Зібрання чинних міжнародних договорів України. - 1990. - № 1. - Ст. 320.

${ }^{6}$ Бернська конвенція про охорону літературних і художніх творів : Конвенція, Міжнародний документ від 24 липня 1971 року // Зібрання чинних міжнародних договорів України. $-2006 .-$ № 5 / Книга 2 /. - Ст. 1247.
} 
Russian Copyright Act of March 20, 1911 were in force in the Ukrainian lands that were at that time part of the Austro-Hungarian and Russian empires ${ }^{7}$.

In its comprehensive distribution, the category 'intellectual property', in the modern sense, was received in the second half of the 20th century only. So, Part 2 of Art. 27 of the Universal Declaration of Human Rights (1948) stated that 'Every person has the right to protect his moral and material interests, which are the result of scientific, literary or artistic works of which he/she is the author ${ }^{8}$. That is, the Declaration approved and guaranteed the human right to own and use the results of its intellectual and creative activity as an important component of the 'universal ideal' of human rights.

Respect for property rights, as one of the fundamental human rights, and scientific and technological progress, helped to recognize and consolidate in the International Covenant on Economic, Social and Cultural Rights (1966) as the human rights of using the results of scientific progress and apply these results in practice, as well as enjoy the protection of moral and material interests arising in connection with any scientific, literary or artistic works to which they are the authors (Art. 15 of the Covenant) ${ }^{9}$.

In the following 1967, the Convention on the Establishment of the World Intellectual Property Organization (WIPO) was adopted. The activities of WIPO and individual states of the world (Great Britain, USA, France and Switzerland, etc.) contributed to the implementation of the Convention's intellectual property rights protection mechanisms. First of all, copyright law. Thus, in 1971 and 1979, the contracting parties, who were 'inspired by the same desire to protect as effectively and equally as possible the rights of authors, their literary and artistic works,' were updated by the Bern Convention on the Protection of Literary and Artistic Works $^{10}$.

\footnotetext{
${ }^{7}$ Prawo własności intelektualnej / Red. naukowa J. Sieńczyło-Chlabicz. Seria Akademicka. - Warszawa: WoltersKluwer, 2015. - S. 34.

8 Загальна декларація прав людини : прийнята та проголошена резолюцією Генеральної Асамблеї ООН від 10 грудня 1948 року № 217 А (III) // Офіційний вісник України. - 2008. - № 93. - Ст. 3103.

9 Міжнародний пакт про економічні, соціальні і культурні права від 16 грудня 1966 року : ратифікований Указом Президії Верховної Ради УРСР від 19 грудня 1973 року № 2148-VIII // Международные акты о правах человека. Сборник документов. - М. : НОРМА-ИНФРА-М, 1998. C. 44-52.

10 Бернська конвенція про охорону літературних і художніх творів : Конвенція, Міжнародний документ від 24 липня 1971 року // Зібрання чинних міжнародних договорів України. - 2006. № 5 /Книга 2 /. - Ст. 1247.
} 
International standards in the field of the establishment and protection of intellectual property rights are now embodied in the Constitution and laws of Ukraine. In particular, Part 1 of Art. 41 of the Constitution of Ukraine states: 'Everyone has the right to own, use and dispose of his property, the results of his/her intellectual and creative activity $^{\text {,11. }}$.

The right of intellectual property, its objects and subjects, the grounds for the emergence, change, termination and renewal, property rights and personal non-proprietary rights to intellectual property objects, the forms of use of these objects, as well as cases of lawful use, without the consent of the author (creator), etc., are regulated by the Civil Code of Ukraine (Art. 433-448 and others), the Laws of Ukraine On Copyright and Related Rights, On the Protection of Rights to Trademarks for Goods and Services, On Protection of Rights to Inventions and Utility Models, On the Protection of Rights to Industrial Designs, and other Acts of the Legislation in force ${ }^{1213141516}$.

The norms regulating relations in the field of intellectual property rights, as stated in the Decree of the Plenum of the Supreme Economic Court of Ukraine dated October 17, 2012, No. 12 On Some Issues in the Practice of Resolving Disputes related to the Protection of Intellectual Property Rights were also developed in other laws, for example, the laws of Ukraine On the Distribution of Copies of Audio-visual Works, Phonograms of Videograms, Computer Programs and Databases, On the Peculiarities of State Regulation of the Activities of Economic Entities associated with Production, Export, Import of Disks for Laser Reading Systems, On the Breeding Business in Livestock, On Scientific and Technical Information, On Protection against Unfair Competition, On State Regulation in the Field of Technology Transfer, and On Medicines,

\footnotetext{
${ }^{11}$ Конституція України : прийнята на п’ятій сесії Верховної Ради України 28 червня 1996 року // Відомості Верховної Ради України. - 1996. - № 30. - Ст. 141.

${ }^{12}$ Цивільний кодекс України : від 16 січня 2003 року // Відомості Верховної Ради України. 2003. - № 40. - Ст. 356.

13 Про авторське право і суміжні права : Закон України від 23 грудня 1993 року // Відомості Верховної Ради України. - 1994. - № 13. - Ст. 64.

${ }^{14}$ Про охорону прав на знаки для товарів і послуг : Закон України від 15 грудня 1993 року // Відомості Верховної Ради України. - 1994. - № 7. - Ст. 36.

${ }^{15}$ Про охорону прав на винаходи і корисні моделі : від 15 грудня 1993 року // Відомості Верховної Ради України. - 1994. - № 7. - Ст. 32.

16 Про охорону прав на промислові зразки від 15 грудня 1993 року // Відомості Верховної Ради України. - 1994. - № 7. - Ст. 34.
} 
etc. ${ }^{17}$ The Ministry of Economic Development and Trade of Ukraine has been working to improve the legislation on the protection of citizens' rights to intellectual property during 2017-2019.

Proceeding from the normative content of the aforementioned acts of the legislation, the right of intellectual property belongs to the persons who are the creators of the object of intellectual property rights (the author, performer and inventor, etc.) and other subjects, which own personal immaterial and/or proprietary intellectual property rights respectively to the provisions of the law.

Approved in the Constitution and laws and international treaties of Ukraine, the right to intellectual property rights is guaranteed and protected by the state and society. At the same time, an institute of forensic examination on intellectual property matters is an important element in the mechanism of judicial protection of this right.

As you know, the implementation of the provisions of the Decree of the President of Ukraine No. 285 dated April 27, 2001 On Measures to Protect Intellectual Property in Ukraine, our state has joined a number of international treaties in the field of protection of the right to intellectual property, and has taken measures the establishment in Ukraine of an effective institutional mechanism for the approval and protection of intellectual property rights. In particular, the creation of a patent library in Ukraine and the study of the possibility of creating a specialized patent court, ${ }^{18}$ etc.

On the implementation of the said Decree of the President of Ukraine dated April 27, 2001 № 285 by the order of the Ministry of Justice of Ukraine dated January 17, 2002, No. 4/5. List of the main types of forensic examination and expert specialties, which assigns the qualification of a forensic expert to the Research Centre for Forensic Examination on Intellectual Property (RCFEIP) specialists to the Ministry of Justice and workers who do not work at such RCFEIP were supplemented by examination in the field of intellectual property. In the same year, the Central Experts and Qualifications Commission of the Ministry of Justice certified the first forensic experts in the field of

\footnotetext{
17 Про деякі питання практики застосування господарськими судами законодавства про захист прав на об’єкти інтелектуальної власності : Оглядовий лист Вищого господарського суду України від 28 лютого 2017 p. № 01-06/ 521 // Електронний ресурс. Режим доступу: https://zakon.rada.gov.ua/laws/show/v_521600-17 - назва з екрану.

${ }^{18}$ Про заходи щодо охорони інтелектуальної власності в Україні: Указ Президента України від 27 квітня 2001 року № 285 // // Офіційний вісник України. - 2001. - № 18. - Ст. 783.
} 
intellectual property. A Section for Forensic Examination of Intellectual Property Objects as a part of the Scientific Advisory and Methodological Council on Forensic Examination (SAMCFE) of the Ministry of Justice was also formed ${ }^{19}$. Thus, the Institute for Forensic Examination on Intellectual Property has been established, since 2002.

An important role in the methodical provision of forensic examination on intellectual on property was played by the generalization of practice by economic courts. Thus, on June 10, 2004, the Supreme Economic Court of Ukraine adopted the Recommendation On Some Issues of the Practice of Resolving Disputes Related to the Protection of Intellectual Property Rights, No. 04-5/1107) and Recommendations On Certain Issues of the Practice of Appointment of Forensic Examinations in Cases Involving Disputes Related to the Protection of Intellectual Property Rights of March 29, 2005, No. 04-5/76 ${ }^{20}$. The relevant Recommendations have proven to be effective and have been developed by economic courts in subsequent years ${ }^{21}$.

On December 31, 2004, according to the order of the Cabinet of Ministers of Ukraine, No. 984-p, a Research Centre for Forensic Examination on Intellectual Property, as a specialized judicial-expert institution, was created on the proposal of the Ministry of Justice, which was assigned to the management of the Ministry of Justice of Ukraine, which carries out research forensic examination on intellectual property ${ }^{22}$. For more than 14 years of its activities, the RCFEIP has established itself as the main research institute of forensic examination ${ }^{23}$. The development of this type of forensic examination led to its methodological justification, the results of which now have their implementation in 9 methods,

\footnotetext{
${ }^{19}$ Крайнєв П.П. Судова експертиза з питань інтелектуальної власності / П.П. Крайнєв // Судова експертиза. - 2004. - № 1. - С. 11-12.

${ }^{20}$ Гаврилішин А.П. Захист права інтелектуальної власності господарськими судами України / А.П. Гаврилішин, А.А. Новак // Порівняльно-аналітичне право. - 2013. - № 4. - С. 102.

${ }^{21}$ Про деякі питання практики вирішення спорів, пов'язаних із захистом прав інтелектуальної власності : Постанова Пленуму Вищого господарського суду України : від 17 жовтня 2012 р. № 12 // Вісник господарського судочинства. - 2012. - № 6. - Ст. 57.

22 Про утворення Науково-дослідного центру судової експертизи 3 питань інтелектуальної власності : Розпорядження Кабінету Міністрів України від 31 грудня 2004 р. № 984 // Офіційний вісник України. - 2005. - № 1. - СТ. 37.

${ }^{23}$ Федоренко В.Л. Становлення та розвиток Науково-дослідного центру судової експертизи 3 питань інтелектуальної власності Міністерства юстиції України (2004-2017рр.) / В.Л. Федоренко // Проблеми теорії та практики судової експертизи з питань інтелектуальної власності : Матер. науковопракт. конф. (21 грудня, 2017 р., м. Київ) ; за заг. ред. проф. В.Л. Федоренка ; Науково-дослідний центру судової експертизи 3 питань інтелектуальної власності Міністерства юстиції України. - К. : Видавництво Ліра-К, 2017. - С. 8-14.
} 
numerous methodological recommendations, textbooks, monographs and other publications.

Thus, forensic examination on intellectual property is a deliberate activity aimed at obtaining evidence on the protection of the right to intellectual property, the content of which is to be investigated by court experts on the basis of special knowledge in the field of copyright, trademark rights for goods and services, industrial property rights, intellectual property, objects, phenomena and processes, in order to provide objective and well-grounded findings that are or will be subject of legal proceedings.

However, the Research Centres for Forensic Examination on Intellectual Property (RCFEIP) activities is not limited to forensic examination of the RCFEIP of the Ministry of Justice, according to Resolution of the Cabinet of Ministers of Ukraine dated July 27, 2011, No. 804 that states the followings: 'At the request of individuals or legal entities conducting expert investigations using means and methods of forensic examination, the results of which are issued as conclusions of expert studies, the provision of consultations requiring special knowledge $e^{24}$.

In addition to forensic examinations, protection of objects of intellectual property rights is carried out by conducting expert investigations by certified expert specialists, the results of which are issued as follows: (a) Conclusions of expert studies; an (b) Advisory reports (Conclusions). The latter, taking into account the practice of the RCFEIP activities in 2005-2019, protect the right to intellectual property rights when conducting tender procedures and providing administrative services.

\section{Classification of Forensic Examination on Intellectual Property}

The category 'classification of forensic examinations on intellectual property' is derived from the other, generic category as 'classification of forensic examinations', and is quite studied in legal science and expert studies. In its turn, the basis of knowledge about the classification of forensic examinations is the content of the category 'classification' (from 'classis' means 'category' and 'fixation') means '... the division of objects

\footnotetext{
24 Деякі питання надання платних послуг науково-дослідними установами судових експертиз Міністерства юстиції України : Постанова Кабінету Міністрів України від 27.07 .2011 р. № 804 // Офіційний вісник України. - 2011. - № 57. - Ст. 2296.
} 
according to common features from the formation of a system of classes of a given set of objects', or '.. a system of distribution of objects, phenomena or concepts to classes, groups on special features, ' etc ${ }^{25} 26$.

In accordance, the classification of forensic examinations on intellectual property is purposeful scientific and practical activity on their distribution, on the basis of pre-identified criteria, on certain types (classes) and groups of forensic examination of objects of intellectual property right with the aim of further systematization.

At the same time, the classification of forensic examinations has not only theoretical and methodological but also practical application, since it allows optimizing forensic expert activity on intellectual property issues, to determine the tendencies of its development, and to identify among them the key areas of development of this type of forensic examination.

The classification of forensic examination on intellectual property is carried out in accordance with certain criteria (from the Greek word 'крıти́рıv' is 'a means of judgment'), which is commonly understood as '... the features taken as the basis of classification, 27 appropriate examination. Based on the commonly used criteria for classifications of forensic examinations on intellectual property issues, the current provisions of the current legislation on intellectual property rights and the Regulations on the appointment and conducting of forensic examinations and expert researches and scientific and methodological recommendations on the preparation and appointment of forensic examinations and expert research, approved by the Order of the Ministry of Justice of Ukraine of October 08, 1998, No. 53/5, the Regulations on Expert-Qualification Commissions and Attestation of Forensic Experts, approved by the Order of the Ministry of Justice of Ukraine dated March 3, 2015, No. 301/5 on the List of Types of Forensic Examinations and Expert Specialties ${ }^{28}$.

\footnotetext{
${ }^{25}$ Словник іншомовних слів / Уклад.: С.М. Морозов, Л.М. Шкарапута. - К. : Наук. думка, 2000. C. 271.

${ }^{26}$ Український тлумачний словник (тезаурус) 25000 слів / уклад. і гол. ред. В.Т. Бусел. - К.; Ірпінь: ВТФ «Перун», 2016. - С. 511.

${ }^{27}$ Словник іншомовних слів / Уклад.: С.М. Морозов, Л.М. Шкарапута. - К. : Наук. думка, 2000. C. 305 .

${ }^{28}$ Про затвердження Інструкції про призначення та проведення судових експертиз та експертних досліджень та Науково-методичних рекомендацій 3 питань підготовки та призначення судових експертиз та експертних досліджень : Наказ Міністерства юстиції України від 08 жовтня 1998 року № 53/5 // Офіційний вісник України. - 1998. - № 46. - Ст. 172.

29 Про затвердження Положення про експертно-кваліфікаційні комісії та атестацію судових експертів : Наказ Міністерства юстиції України від 03 березня 2015 р. № 301/5 // Офіційний вісник України. - 2015. - № 17. - Ст. 468.
} 
At one time P.P. Krainev substantiated the complex classification of forensic examinations on intellectual property. Taking into account the properties of the objects of intellectual property rights, the scientist proposed to distinguish the followings: (a) objects of industrial property rights (objects of patent law and means of individualization (designation)); (b) objects of copyright and related rights; and (c) other objects of intellectual property rights (commercial secrets, including know-how and termination of unfair competition $)^{30}$. Nowadays, scientists identify the types of relevant examination mainly with expert specialties even in the ground-breaking editions on forensic examination in Ukraine $^{31}$.

At the same time, the classification of forensic intellectual property examinations in today's conditions requires a system of criteria that will help to identify all of their diversity and properties, to measure the potential for forensic examination on intellectual property issues. In our opinion, such criteria are the followings: (1) objects of intellectual property rights and their properties; (2) the type of procedural proceedings, within which a forensic examination on intellectual property is conducted; (3) subjects of appointment and order of forensic examination on intellectual property; (4) the grounds and procedure for the appointment of forensic examination on intellectual property; and (5) the subject of the forensic examination on intellectual property, etc.

\section{Characteristics of Certain Types of Forensic Examination on Intellectual Property in Ukraine}

3.1. Often, the basis of the classification of forensic examination on intellectual property takes into account classification of the objects of intellectual property rights themselves. According to Art. 420 of the Civil Code of Ukraine, the objects of intellectual property law include the followings: (1) literary and artistic works; (2) computer programs; (3) data compilation (database); (3) performance; (4) phonograms, videograms, broadcasts (programs) of broadcasting organizations; 5) scientific discoveries; (6) inventions, utility models, industrial designs; (7) layout

\footnotetext{
${ }^{30}$ Крайнєв П.П. Судова експертиза у сфері інтелектуальної власності ; за ред. П.П. Крайнєва / П.П. Крайнєв, Н.М. Ковальова, М.В. Мельников. - Вінниця : ПП «Поліграф. Центр «Фенікс»; ДІВП ВАТ «Інфракон»- «Інфракон-І», 2008. - С. 20-26.

${ }^{31}$ Основи судової експертизи : навч. посібн. / автор.-уклад.: Л.М. Головченко, А.І. Лозовий, Е.Б. Сімакова-Сфремян та ін. - Х. : Право, 2016. - С. 409.
} 
(topography) of integrated circuits; (8) innovative proposals; (9) plant varieties, breeds of animals; (10) commercial (firm) name, trademarks (signs for goods and services), geographical indications; and (11) commercial secrets, etc ${ }^{32}$.

In the Agreement on the Association between Ukraine, on the one hand, and the European Union, the European Atomic Energy Community and their Member States, on the other hand of 16 September 2014, which was enacted in September 2017, following its ratification by the Netherlands, in effect, Chapter 9 Intellectual Property in Part 2 defined the standards for the following objects of intellectual property rights: (1) copyright and related rights; (2) computer programs; 3) data compilation (database); (4) phonograms, videograms, broadcasts (programs) of broadcasting organizations, including cable broadcasting; (5) trademarks; (6) geographical indications; (7) industrial designs; (8) inventions (patents); (9) topography of semiconductor products; (10) varieties of plants and breeds of animals; and (11) genetic resources, traditional knowledge and folklore, etc $^{33}$.

Similar approaches are widespread in many foreign countries. For example, in the Polish textbook Intellectual Property Rights (2015), the following objects are distinguished: (1) copyright and related rights; (2) audio-visual works; (3) the database; (4) computer programs; (5) the image and the addressee of the correspondence; (6) patent law; (7) the right of trademarks; (8) the right of industrial designs; (9) geographical designation; (10) samples of utility products; and (11) topography of chips $^{34}$. Although, it should be noted that among forensic examinations conducted in Poland, in particular, in the Institute for Forensic Examination. Dr., prof. J. Zegn in Krakow (Ministry of Justice), has no legal examination on intellectual property.

To date, it is enshrined in Clause 1.2.5 of the Instruction on the Appointment and Conducting of Forensic Examinations and Expert Researches, approved by the Order of the Ministry of Justice of Ukraine of October 08, 1998, No. 53/5, and in Appendix 6 to the Regulations on

\footnotetext{
32 Цивільний кодекс України : від 16 січня 2003 року // Відомості Верховної Ради України. 2003. - № 40. - Ст. 356.

33 Угода про асоціацію між Україною, з однієї сторони, та Європейським Союзом, Європейським співтовариством з атомної енергії і їхніми державами членами, з іншої сторони від 16 вересня 2014 р. // Офіційний вісник України. - 2014. - № 75 /Т. 1/. - Ст. 2125.

${ }^{34}$ Prawo własności intelektualnej / Red. naukowa J. Sieńczyło-Chlabicz. Seria Akademicka. - Warszawa: WoltersKluwer, 2015. - $607 \mathrm{~s}$.
} 
Expert-Qualification Commissions and Certification of Forensic Experts (Paragraph 3 of Section 5), approved by the Order of the Ministry of Justice of Ukraine dated 03.03.2015 № 301/5, List of Types of Forensic Examinations, upon which the qualification of a judicial expert is assigned to specialists of research institutions of forensic examinations, hereinafter referred to as 'RCFEIP' of the Ministry of Justice (Table 1), according to which RCFEIP court experts and court experts who are not employees of the RCFEIP, as a whole, reproduce a system of objects of intellectual property rights enshrined in the Civil Code of Ukraine ${ }^{35} 36$. Actually, the classification of forensic examinations on intellectual property in Table 1 is the most widespread, and in the new Guide for Intellectual Property Judges $(2018)^{37}$ is no alternative.

Not all types of expert specialties on intellectual property, from the List above, appeared to be in demand for forensic and research activity. Given that the Specialty 13.5.1: Plant Variety Investigations is currently represented in Ukraine by only 1 forensic expert, real experience in carrying out relevant expert researches and has prospects for development, at the autumn meetings of profile Sections of the SAMCFE was decided: to leave both the Specialty 13.5.1 unchanged, and the Specialty 13.5.2: Animal-related Researches and the Specialty 13.7: Researches related to topographies of integrated circuits (chips) to remove from the List of Types of Forensic Examinations according to which the qualification of a forensic expert is assigned to specialists of research institutions of forensic examinations of the Ministry of Justice without changing the names of other specialties and their numbering, with the possibility of their recovery in real need. The corresponding decision was supported on December 20, 2018 by the Presidium of the SAMCFE under the Ministry of Justice of Ukraine.

\footnotetext{
35 Про затвердження Інструкції про призначення та проведення судових експертиз та експертних досліджень та Науково-методичних рекомендацій 3 питань підготовки та призначення судових експертиз та експертних досліджень : Наказ Міністерства юстиції України від 08 жовтня 1998 року № 53/5 // Офіційний вісник України. - 1998. - № 46. - Ст. 172.

36 Про затвердження Положення про експертно-кваліфікаційні комісії та атестацію судових експертів : Наказ Міністерства юстиції України від 03 березня 2015 р. № 301/5 // Офіційний вісник України. - 2015. - № 17. - Ст. 468.

37 Посібник для суддів $з$ інтелектуальної власності / Бендисюк І.М. та ін. - К.: К.І.С., 2018. C. $370-371$.
} 
Table 1 List of Types of Forensic Examinations by which the Qualification
of a Forensic Expert is assigned to Specialists of Research Institutions
of Forensic Examinations of the Ministry of Justice

\begin{tabular}{|c|c|c|c|}
\hline $\begin{array}{l}\text { Item } \\
\text { No. }\end{array}$ & $\begin{array}{l}\text { Types and Subspecies of } \\
\text { Forensic Examinations }\end{array}$ & $\begin{array}{l}\text { Indices of } \\
\text { Expert } \\
\text { Specialties }\end{array}$ & Types of Expert Specialties \\
\hline \multicolumn{4}{|c|}{ Intellectual Property Examination } \\
\hline \multirow[b]{2}{*}{30.1 . } & \multirow[b]{2}{*}{ Literary and artistic works } & 13.1 .1 & $\begin{array}{l}\text { Researches related to literature } \\
\text { and works of art and others; }\end{array}$ \\
\hline & & 13.1.2. & $\begin{array}{c}\text { Researches related to } \\
\text { computer programs and data } \\
\text { compilations (databases); }\end{array}$ \\
\hline 30.2 . & $\begin{array}{l}\text { Phonograms, videograms, } \\
\text { programs (broadcasts) of } \\
\text { broadcasting organizations; }\end{array}$ & 13.2. & $\begin{array}{c}\text { Researches related to } \\
\text { performances, phonograms, } \\
\text { videograms, programs } \\
\text { (broadcasts) of broadcasting } \\
\text { organizations; }\end{array}$ \\
\hline 30.3 & Inventions and utility models; & 13.3. & $\begin{array}{c}\text { Research related to inventions } \\
\text { and utility models; }\end{array}$ \\
\hline 30.4 . & Industrial samples; & 13.4 . & $\begin{array}{l}\text { Researches related to } \\
\text { industrial samples; }\end{array}$ \\
\hline \multirow{2}{*}{30.5 . } & \multirow{2}{*}{$\begin{array}{l}\text { Varieties of plants and animal } \\
\text { breeds; }\end{array}$} & 13.5.1. & $\begin{array}{l}\text { Researches related to plant } \\
\text { varieties; }\end{array}$ \\
\hline & & 13.5.2. & $\begin{array}{c}\text { Researches related to animal } \\
\text { breeds; }\end{array}$ \\
\hline 30.6 . & $\begin{array}{c}\text { Commercial (branded) names, } \\
\text { trademarks (trademarks and } \\
\text { service marks) and } \\
\text { geographical names } \\
\text { (indications); }\end{array}$ & 13.6. & $\begin{array}{c}\text { Researches related to } \\
\text { commercial (branded) names, } \\
\text { trademarks (marks of goods } \\
\text { and services), geographical } \\
\text { names (indications). }\end{array}$ \\
\hline 30.7 . & $\begin{array}{l}\text { Topographies of integrated } \\
\text { circuits (chips); }\end{array}$ & 13.7. & $\begin{array}{l}\text { Researches related to } \\
\text { topographies of integrated } \\
\text { circuits (chips); }\end{array}$ \\
\hline 30.8. & $\begin{array}{l}\text { Commercial secrets (know- } \\
\text { how) and innovative offers; }\end{array}$ & 13.8. & $\begin{array}{c}\text { Researches related to } \\
\text { commercial secrets (know- } \\
\text { how) and rationalization } \\
\text { proposals; }\end{array}$ \\
\hline 30.9 . & $\begin{array}{l}\text { Economic examination on } \\
\text { intellectual property; }\end{array}$ & 13.9. & $\begin{array}{l}\text { Economic researches on } \\
\text { intellectual property. }\end{array}$ \\
\hline
\end{tabular}


3.2. An equally important criterion for the classification of expert research on intellectual property is subjects of their holding. Relevant subjects are defined in Art. 7 of the Law of Ukraine On Forensic Examination and Procedural Codes of Ukraine. They are as follows: (1) research institutions of forensic examination (RSFEIP); (2) forensic experts who are not the RSFEIP employees; and (3) other specialists (experts) from the relevant branches of knowledge ${ }^{38}$.

The state RCFEIP, in accordance with Part 2 of Art. 7 of the Law of Ukraine On Judicial Examination includes as follows: (1) research institutions of forensic examination of the Ministry of Justice of Ukraine; (2) research institutes of forensic examinations, forensic medical and forensic psychiatric institutions of the Ministry of Health of Ukraine; and (3) expert services of the Ministry of Internal Affairs of Ukraine, the Ministry of Defence of Ukraine, the Security Service of Ukraine and the State Border Guard Service of Ukraine ${ }^{39}$.

Although, not all of the above-mentioned RCFEIP are certified forensic experts on intellectual property conducting expert appraisals and expert research in the field of intellectual property. To date, the vast majority of forensic experts on intellectual property are concentrated in the RCFEIP of the Ministry of Justice of Ukraine and the Ministry of Internal Affairs, or is the so-called 'private' court experts who are not employees of the RCFEIP.

Specialized forensic-expert institution with all-Ukrainian competence, which is the most concentrated forensic experts in the field of intellectual property in Ukraine, has been the Research Centre for Forensic Examination on Intellectual Property only, since 2004.

The main subject of forensic examination in the field of intellectual property remains, first of all, the judicial expert. The certified forensic expert is responsible for the quality and objectivity of forensic examination in the field of intellectual property in Ukraine. Abroad, first of all in the EU member states certified forensic experts on intellectual property are rare. The relevant examinations for the courts are carried out by experts whose candidatures are ad hoc appointed by the courts ${ }^{40}$.

\footnotetext{
${ }^{38}$ Про судову експертизу : Закон України від 25 лютого 1994 року // Відомості Верховної Ради України. - 1994. - № 28. - Ст. 232.

${ }^{39}$ Про судову експертизу : Закон України від 25 лютого 1994 року // Відомості Верховної Ради України. - 1994. - № 28. - Ст. 232.

${ }^{40}$ Prawo własności intelektualnej / Red. naukowa J. Sieńczyło-Chlabicz. Seria Akademicka. - Warszawa: WoltersKluwer, 2015. - S. 510-512.
} 
According to Part 1 of Art. 10 of the Law of Ukraine On Forensic Examinations, forensic experts '... may be persons who have the necessary knowledge to provide a conclusion on the issues under investigation $^{41}$. According to the analysis of the Register of Certified Forensic Experts, the number of forensic experts with valid certificates of qualification of a forensic expert on intellectual property as of July 1, 2018 is 107, which is more than in comparison with 2016 for 6 persons.

Forensic experts on intellectual property as of July 1, 2018 have a total of 265 human specialties, which is more compared to 2016 for 9 human specialties. These data indicate a steady state of affairs in the field of training and certification of forensic experts in the field of intellectual property.

An important criterion characterizing the prospects of forensic examination on intellectual property is the dynamics of acquiring (confirming) expert specialties on intellectual property. This criterion makes it possible to identify both the most promising types of forensic examination and those that do not have a prospect of development in Ukraine today.

Its analysis shows the dynamics of development of forensic expert activity on intellectual property issues on the basis of the criterion of acquiring (confirming) relevant expert specialties, the following conclusion can be drawn:

- The largest increase in the share, and consequently the increase in demand for forensic expert practice is observed in the specialties: 13.4: Research related to industrial designs $-3.8 \%$; 13.6: Studies related to commercial (brand) names, trademarks (trademarks and service marks), geographical names (indication) $-3.7 \%$; and 13.9: Economic research in the field of intellectual property $-2.7 \%$;

- The largest reduction of the share, and therefore the decline in the relevance of forensic expert activity is observed in the following specialties: 13.2: Studies related to performances, phonograms, videograms, programs (broadcasts) of broadcasting organizations $-4,1 \%$; 13.1.1: Studies related to literary, artistic works, and others $-4,1 \%$; and 13.2: Studies related to performances, phonograms, videograms, programs (broadcasts) of broadcasting organizations $-2.9 \%$.

\footnotetext{
41 Про судову експертизу : Закон України від 25 лютого 1994 року // Відомості Верховної Ради України. - 1994. - № 28. - Ст. 232.
} 


\section{CONCLUSIONS}

The classification of forensic examinations receives its continuation in integrating the detected types of forensic examination and their groups into the system and the doctrinal, substantive, functional, structural and other interrelationships revealed between them.

The internal structure (structure) of the forensic examination system on intellectual property issues is now represented by the following types of forensic examinations, differentiated according to the following criteria:

- By objects of intellectual property rights and expert specialties:

(1) Researches related to literary, artistic works, and others (13.1.1);

(2) Researches related to computer programs and data compilations (databases) (13.1.2);

(3) Researches related to performances, phonograms, videograms, programs (broadcasts) of broadcasting organizations;

(4) Researches related to inventions and utility models (13.3);

(5) Researches related to industrial samples (13.4);

(6) Researches related to plant varieties (13.5.1);

(7) Researches related to commercial (branded) names, trademarks (marks of goods and services), geographical names (indications) (13.6);

(8) Researches related to commercial secrets (know-how) and rationalization proposals (13.8);

(9) Economic research in the field of intellectual property (13.9).

- By the number of expert specialties on which the following forensic examination is conducted: (1) simple (monoexperiments); (2) complex (complex examinations);

- By types of procedural proceedings, in which the following forensic examination on intellectual property issues is conducted: (1) forensic examinations carried out within the framework of economic legal proceedings; (2) forensic examinations carried out within the framework of civil justice; (3) forensic examinations carried out within the framework of criminal proceedings; (4) forensic examinations carried out within the framework of administrative legal proceedings; and (5) extra-procedural expert researches;

- By subjects of appointment and order of forensic examinations on questions of intellectual property: (1) forensic examinations carried out at the request of enterprises, organizations and institutions, regardless of the forms of their property (legal entities); (2) court examinations carried out by court decisions; (3) forensic examinations conducted on the 
order of individuals and lawyers; (4) forensic examinations carried out at the request of the National Police of Ukraine; and (5) forensic examinations carried out at the request of the prosecutor's office.

- By the grounds and procedure for the appointment of forensic examinations on matters of intellectual property: (1) court orders, including judgments of the investigating judge; (2) a statement (letter) of the customer (physical or legal person) for conducting expert research; (3) ordering an examination by a participant in a civil proceeding; (4) the resolution of the bodies of pre-trial investigation in criminal cases filed before the Unified Register of Pre-trial Investigations (URPTI) till October 3, 2017; and (5) the written application of the victim or the party protecting the criminal proceedings;

- By the complexity of conducting forensic examinations on intellectual property issues: (1) simple; (2) medium complexity; (3) complex and special complexity;

- By subjects of conducting forensic examinations on intellectual property issues: (1) research institutions of forensic examination (RCFEIP); (2) forensic experts who are not the RCFEIP employees; and (3) other specialists (experts) from the relevant branches of knowledge.

- By the number of court experts involved in conducting forensic examination on intellectual property issues: (1) conducted by experts alone; and (2) commission assessments, etc.

The presented types of forensic examinations, as well as their groups, today form a system (from the Greek word ' $\sigma v \sigma \tau \eta \mu \alpha$ ' means combination, formation) of forensic examinations on intellectual property issues is an ordered community of different types of forensic examinations and their groups, interconnected by doctrinal, substantive, functional, structural and other ties, which are aimed at protecting the constitutional right to objects of intellectual property rights.

\section{SUMMARY}

The publication is devoted to actual problems and prospects of development of forensic examination of objects of intellectual property rights in Ukraine in conditions of judicial reform. The main stages of approval and the development of forensic examination in the field of intellectual property in the context of the genesis of critical infrastructure protection mechanisms have identified, since 2002. The main stages of the genesis of forensic examinations of intellectual property issues in Ukraine 
(2002 - 2019) are highlighted, as well as prospects for their further development.

It is noted that the forensic examination on intellectual property issues in Ukraine is new, unique for Europe and the whole world, as well as a dynamic and multifunctional type of forensic examination. This is manifested in the many types of forensic examinations in the field of intellectual property, which are classified according to different criteria: objects of intellectual property right and its properties; the type of procedural proceedings, within which a forensic examination on intellectual property issues is conducted, etc. The relevant types of forensic examinations, as well as their groups, today form the system of forensic examinations on intellectual property issues, which is an instrument for protecting the 'intellectual matrix' of critical infrastructure of Ukraine.

\section{REFERENCES}

1. Бернська конвенція про охорону літературних i художніх творів : Конвенція, Міжнародний документ від 24 липня 1971 року // Зібрання чинних міжнародних договорів України. - 2006. - № 5 /Книга 2/. - Ст. 1247.

2. Бетелл Т. Собственность и процветание : уроки истории / Томм Бетелл ; пер. с англ. Б. Пинскера. - М. ; Челябинск : Социум, 2018. -480 c.

3. Гаврилішин А.П. Захист права інтелектуальної власності господарськими судами України / А.П. Гаврилішин, А.А. Новак // Порівняльно-аналітичне право. - 2013. - № 4. - С. 101-103.

4. Деякі питання надання платних послуг науково-дослідними установами судових експертиз Міністерства юстиції України : Постанова Кабінету Міністрів України від 27.07.2011 p. № 804 // Офіційний вісник України. - 2011. - № 57. - Ст. 2296.

5. Загальна декларація прав людини : прийнята та проголошена резолюцією Генеральної Асамблеї ООН від 10 грудня 1948 року № 217 А (III) // Офіційний вісник України. - 2008. - № 93. - Ст. 3103.

6. Конституція України : прийнята на п’ятій сесії Верховної Ради України 28 червня 1996 року // Відомості Верховної Ради України. 1996. - № 30. - Ст. 141.

7. Крайнєв П.П. Судова експертиза 3 питань інтелектуальної власності / П.П. Крайнєв // Судова експертиза. - 2004. - № 1. C. 9-17. 
8. Крайнєв П.П. Судова експертиза у сфері інтелектуальної власності ; за ред. П.П. Крайнєва / П.П. Крайнєв, Н.М. Ковальова, М.В. Мельников. - Вінниця : ПП «Поліграф. Центр «Фенікс»; ДІВП ВАТ «Інфракон» - «Інфракон-І», 2008. - 376 с.

9. Міжнародний пакт про економічні, соціальні і культурні права від 16 грудня 1966 року : ратифікований Указом Президії Верховної Ради УРСР від 19 грудня 1973 року № 2148-VIII // Международные акты о правах человека. Сборник документов. - М. : НОРМА-ИНФРА-М, 1998. - С. 44-52.

10. Основи судової експертизи : навч. посібн. / автор.-уклад.: Л.М. Головченко, А.І. Лозовий, Е.Б. Сімакова-Сфремян та ін. - Х. : Право, 2016. - 928 с.

11. Охорона інтелектуальної власності в Україні / С.О. Довгий, В.О. Жаров, В.О. Зайчук та ін. - К. : Форум, 2002. - 319 с.

12. Паризька конвенція про охорону промислової власності від 20 березня 1883 року (укр/рос) // Зібрання чинних міжнародних договорів України. - 1990. - № 1. - Ст. 320.

13. Посібник для суддів 3 інтелектуальної власності / Бендисюк I.М. та ін. - К.: К.I.C., 2018. - 424 с.

14. Про авторське право і суміжні права : Закон України від 23 грудня 1993 року // Відомості Верховної Ради України. - 1994. № 13. - Ст. 64.

15. Про деякі питання практики вирішення спорів, пов'язаних із захистом прав інтелектуальної власності : Постанова Пленуму Вищого господарського суду України : від 17 жовтня 2012 р. № 12 // Вісник господарського судочинства. - 2012. - № 6. - Ст. 57.

16. Про деякі питання практики застосування господарськими судами законодавства про захист прав на об'єкти інтелектуальної власності : Оглядовий лист Вищого господарського суду України від 28 лютого 2017 р. № 01-06/ 521 // Електронний ресурс. Режим доступу: https://zakon.rada.gov.ua/laws/show/v_521600-17 - назва 3 екрана.

17. Про затвердження Інструкції про призначення та проведення судових експертиз та експертних досліджень та Науково-методичних рекомендацій з питань підготовки та призначення судових експертиз та експертних досліджень : Наказ Міністерства юстиції України від 08 жовтня 1998 року № 53/5 // Офіційний вісник України. - 1998. № 46. - Ст. 172. 
18. Про затвердження Положення про експертно-кваліфікаційні комісії та атестацію судових експертів : Наказ Міністерства юстиції України від 03 березня 2015 р. № 301/5 // Офіційний вісник України. - 2015. - № 17. - Ст. 468.

19. Про заходи щодо охорони інтелектуальної власності в Україні: Указ Президента України від 27 квітня 2001 року № 285 // Офіційний вісник України. - 2001. - № 18. - Ст. 783.

20. Про охорону прав на винаходи і корисні моделі : від 15 грудня 1993 року // Відомості Верховної Ради України. - 1994. № 7. - Ст. 32 .

21. Про охорону прав на знаки для товарів і послуг : Закон України від 15 грудня 1993 року // Відомості Верховної Ради України. - 1994. - № 7. - Ст. 36.

22. Про охорону прав на промислові зразки від 15 грудня 1993 року // Відомості Верховної Ради України. - 1994. - № 7. Ст. 34.

23. Про судову експертизу : Закон України від 25 лютого 1994 року // Відомості Верховної Ради України. - 1994. - № 28. Ст. 232.

24. Про утворення Науково-дослідного центру судової експертизи з питань інтелектуальної власності : Розпорядження Кабінету Міністрів України від 31 грудня 2004 р. № 984 // Офіційний вісник України. - 2005. - № 1. - Ст. 37.

25. Словник іншомовних слів / Уклад.: С.М. Морозов, Л.М. Шкарапута. - К. : Наук. думка, 2000. - 680 с.

26. Федоренко В.Л. Становлення та розвиток Науководослідного центру судової експертизи 3 питань інтелектуальної власності Міністерства юстиції України (2004-2017 рр.) / В.Л. Федоренко // Проблеми теорії та практики судової експертизи 3 питань інтелектуальної власності : Матер. науково-практ. конф. (21 грудня, 2017 р., м. Київ) ; за заг. ред. проф. В.Л. Федоренка ; Науково-дослідний центру судової експертизи 3 питань інтелектуальної власності Міністерства юстиції України. - К. : Видавництво Ліра-К, 2017. - С. 8-14.

27. Угода про асоціацію між Україною, 3 однієї сторони, та Європейським Союзом, Європейським співтовариством 3 атомної енергії і їхніми державами членами, з іншої сторони від 16 вересня 2014 р. // Офіційний вісник України. - 2014. - № 75 /Т. 1/. - Ст. 2125. 
28. Український тлумачний словник (тезаурус) 25000 слів / уклад. і гол. ред. В.Т. Бусел. - К.; Ірпінь: ВТФ «Перун», 2016. $1696 \mathrm{c}$.

29. Цивільний кодекс України : від 16 січня 2003 року // Відомості Верховної Ради України. - 2003. - № 40. - Ст. 356.

30. Fedorenko W. Udział ekspertów sądowych w ochronie praw własności intelektualnej na Ukrainie i za granicą / W. Fedorenko // Nowe wyzwania i rozwiązania w europejskim systemie ochrony praw człowieka. Red. naukowa J. Jaskiernia, K. Sprzyszak. - Toruń: Wydawnictwo Adam Marszałek, 2018. - S. 510-520.

31. Prawo własności intelektualnej / Red. naukowa J. SieńczyłoChlabicz. Seria Akademicka. - Warszawa: WoltersKluwer, 2015. - 607 s.

\section{Information about the authors:} Fedorenko V. L.

Doctor of Law, Professor, Director of the Scientific\&Research Center of Forensic Expertise on Intellectual Property of the Ministry of Justice of Ukraine, Honored Lawyer of Ukraine, Forensic Expert of the Higher Qualification Class 26, boulevard 1. Ukrainka, Kyiv, 01133, Ukraine fedorenko900@gmail.com ORCID 0000-0001-5902-1226 